\title{
Novel Primers and Sampling for PCR Detection of Xylella fastidiosa in Peach
}

\author{
Chunxian Chen, ${ }^{1, \dagger}$ Clive H. Bock, ${ }^{1}$ and Phillip M. Brannen ${ }^{2}$ \\ ${ }^{1}$ U.S. Department of Agriculture, Agricultural Research Service, Southeastern Fruit and Tree Nut Research Laboratory, 21 Dunbar Road, Byron, \\ GA 31008; and 2University of Georgia, Department of Plant Pathology, 3307 Miller Plant Sciences Building, Athens 30602. \\ Accepted for publication 14 November 2018.
}

\begin{abstract}
Epidemics of phony peach disease (PPD), caused by Xylella fastidiosa, are of increasing concern to peach (Prunus persica) producers in the southeastern United States. Primers suitable for both conventional PCR (cPCR) and quantitative PCR (qPCR), along with optimal tissue and sampling time, are needed for comparative and reliable detection of $X$. fastidiosa. In this study, we developed and assessed novel primers for $X$. fastidiosa and for peach and compared detection of $X$. fastidiosa in four peach tissue types sampled at three time points using both $\mathrm{cPCR}$ and qPCR. Primer C06Xf-bamA was extensively tested for reliable detection of $X$. fastidiosa due to the more consistent intensity of the $\mathrm{cPCR}$ products and the marginally lower average quantification cycle $(\mathrm{Cq})$ values of the qPCR products, compared with the other primers screened. Among the four peach tissue types tested, only root samples demonstrated reliable and

consistent detection of $X$. fastidiosa; stem, petiole, and leaf samples, regardless of source trees, primers used, sampling times, or PCR methods (cPCR or qPCR), were unreliable for detection, due to insufficient quantity of DNA of $X$. fastidiosa in these samples based on the relative quantification assay. The Cq means and ratios were compared and statistically analyzed, to ascertain effects of source tree, tissue type, sampling time, and primer. Differences in detection sensitivity and the Cq means among sampled trees, sampling times, tested primers, and tissues (except root) were not significant or were inconsistent precluding further exploitation. In summary, these novel primers are a useful resource for detecting X. fastidiosa, and based on our results, root is the only tissue type reliable for year-round detection of $X$. fastidiosa in peach. Further research on potential utilization of aboveground tissues for PCR detection of $X$. fastidiosa are discussed.
\end{abstract}

Phony peach disease (PPD) was first observed in the 1890s in peach (Prunus persica) trees near Marshallville, Georgia (Neal 1920; Turner 1949). Since its first report, PPD spread rapidly through the southeastern region and epidemics have occurred periodically (French and Crocker 1980; Janse and Obradovic 2010). Recently, PPD was reported in the southwestern region (Randall et al. 2011). A trend of increasing incidence of PPD, perhaps due to unusually warm winters favoring high vector populations, is of serious concern as it indicates a new epidemic of PPD threatens the southeastern peach industry (P. Brannen, personal communication). Sharpshooters (Cicadellidae) are the main vector. There is no cure or effective control for PPD, largely due to the nature of the pathogen, the broad range of vectors and hosts, and limited knowledge of host resistance in Prunus germplasm (Ledbetter and Rogers 2009). Removal of symptomatic trees is a management approach utilized to reduce the spread of PPD. However, the approach is very inefficient as the disease can spread from trees that are infected but asymptomatic, and as there can be many months between infection and symptom development (French and Crocker 1980). PPD is now known to be caused by Xylella fastidiosa, a gram-negative, vector-transmitted, xylem-inhabiting, and slow-

${ }^{\dagger}$ Corresponding author: Chunxian Chen; E-mail: chunxian.chen@ars.usda.gov

Funding: The research was supported by the U.S. Department of AgricultureAgriculture Research Service through project 6606-21000-004-00D and 660621220-011-00D

This article reports the results of research only. Mention of a trademark or proprietary product is solely for the purpose of providing specific information and does not constitute a guarantee or warranty of the product by the U.S. Department of Agriculture and does not imply its approval to the exclusion of other products that may also be suitable.

*The $\boldsymbol{e}$-Xtra logo stands for "electronic extra" and indicates that three supplementary figures and three supplementary tables are published online.

This article is in the public domain and not copyrightable. It may be freely reprinted with customary crediting of the source. The American Phytopathological Society, 2019. growing bacterium, which was first cultured from grapevines (Vitis spp.) (Davis et al. 1978), in which host it causes Pierce's disease (PD). Host specialization and genetic/genomic analysis have defined three well-accepted subspecies, i.e., subsp. fastidiosa, multiplex, and pauca, and proposed other subspecies, including sandyi, morus, and tashke, which arguably may be new members of $X$. fastidiosa subsp. fastidiosa (Almeida and Nunney 2015; Janse and Obradovic 2010; Marcelletti and Scortichini 2016; Randall et al. 2009; Schaad et al. 2004). X. fastidiosa subsp. multiplex causes PPD (Schaad et al. 2004) and plum leaf scald (PLS), which are reciprocally transmissible but develop distinct symptoms (French 1982). At least 14 complete (circular) genomes of different $X$. fastidiosa subspecies have been assembled and deposited in GenBank (Chen et al. 2013; Chen et al. 2010; Giampetruzzi et al. 2015; Giampetruzzi et al. 2017; Nunney et al. 2014; Schreiber et al. 2010; Schuenzel et al. 2005; Simpson et al. 2000; Van Sluys et al. 2003). A further new draft genome from a strain of $X$. fastidiosa subsp. fastidiosa was reported very recently (Landa et al. 2018). The existence of these subspecies complicates studies on epidemiological questions and detection of the bacterium.

The enzyme-linked immunosorbent assay (ELISA) and polymerase chain reaction (PCR) are two widely used techniques to detect X. fastidiosa, for example in grapevines (Baldi and La Porta 2017; Banks et al. 1999; Jimenez and Ingalls 1990; Krivanek and Walker 2005; Nome et al. 1980; Rodrigues et al. 2003; Ruel and Walker 2006), but rarely in peaches (Banks et al. 1999). ELISA used for detection of $X$. fastidiosa in PPD trees often yielded uncertain and/or unreproducible results (T. Beckman, personal communication). Assessment of existing or novel PCR methods and primers for detection of $X$. fastidiosa in PPD trees remains scarce. Besides, almost all existing PCR primers were specifically designed and/or validated for subspecies or strains of $X$. fastidiosa in other host species. Furthermore, many of these primers are suitable only for conventional PCR (cPCR) and visualization on agarose gels, but not for quantitative PCR (qPCR) using real-time machines. For example, two primers were designed for detection of the strain of $X$. fastidiosa subsp. fastidiosa in grapevine causing PD, one amplifying a 779-bp fragment specific to 34 samples of PD, and the 
other amplifying a 511-bp fragment specific to the remaining 98 samples of PD. These two primers could not detect strains of $X$. fastidiosa causing citrus variegated chlorosis (CVC), mulberry leaf scorch, oak leaf scorch, periwinkle wilt, PPD, or PLS (Banks et al. 1999). In another study, two 16S rDNA primer pairs (producing expected amplicons of 745 and $603 \mathrm{bp}$, respectively) and one gyrB primer pair (409 bp), were developed from 18 strains of $X$. fastidiosa and were used successfully for detection of $X$. fastidiosa in field-collected plants (including almond), vector insects, and infected but asymptomatic plants. Based on the gyrB amplicon sequences, strains from grape, strains from citrus and coffee, and strains from all other hosts fell into three distinct clusters (Rodrigues et al. 2003). A new primer pair was used to amplify a 521-bp fragment from strains of $X$. fastidiosa subsp. multiplex isolated from almond, and provided a useful cPCR test to detect some strains causing almond leaf scorch (ALS) (HernandezMartinez et al. 2006). Primers HL5 and HL6 were developed for cPCR and qPCR to amplify a unique 221-bp region shared by four genomes of $X$. fastidiosa, which could detect strains associated with PD, ALS, oleander leaf scorch and a strain associated with CVC. The cycle threshold $(\mathrm{Ct})$ values of the qPCR ranged from 20 to 36 for 5 to 10 bacterial cells per reaction, suggesting a high degree of sensitivity and specificity (Francis et al. 2006). Primers HL5 and HL6 were also used for detection of $X$. fastidiosa in olive trees and spittlebug vectors (Cornara et al. 2016; Cornara et al. 2017; Haelterman et al. 2015). However, most of the primers were selectively developed for detection of strains from specific hosts (Janse and Obradovic 2010) and have not been validated for detection of $X$. fastidiosa strains from phony peach trees. Indeed, some recent tests have found that these primers are not always reliable and fail to amplify strains from some hosts (Reisenzein 2017). Unreliability in some cases may be due to mutations in primer annealing sequences in the target region (Baldi and La Porta 2017; Livingston et al. 2010). As stated previously, most of these primers (except HL5 and HL6) yielded large amplicons and/or were from multiple-copy rDNA regions only appropriate for cPCR, but unsuitable for more sensitive, higher throughput qPCR that requires single-copy gene sequences producing small amplicons. Therefore, new primers for detection of $X$. fastidiosa in peach trees based on single-copy gene sequences producing optimally sized small amplicons for both $X$. fastidiosa and peach reference genes (used as a DNA extraction control) are needed for use in both qPCR and cPCR methods.

The success of ELISA and PCR relies on the titer of $X$. fastidios in sampled tissues, which can be too low for unambiguous and reproducible detection. Therefore, knowledge of the seasonal titer and detection sensitivity of $X$. fastidiosa in different host tissues will facilitate optimal sampling. An early study of the bacterial distribution showed roots tended to have the highest bacterial counts in PPD trees (Wells et al. 1980). Another comparative study of bacterial counts in roots of symptomatic and asymptomatic phony peach trees revealed that the population of the bacterium was higher, the distribution was more uniform, and the minimal root sample size required for $95 \%$ probability to detect the bacteria was significantly lower in symptomatic trees, compared with asymptomatic trees. In other words, infected asymptomatic peach trees would have been underestimated, depending on root sample size per tree (Aldrich et al. 1992). Although no DNA was extracted from root tissues or quantified in either study, both studies suggested that roots might be the host tissue that had the highest titer of $X$. fastidiosa. Sampling roots generally is much more time-consuming compared with sampling above-ground tissues. Therefore, rather than counting the bacteria, extracting DNA from different tissues (including roots) and using PCR to assess the seasonal titer and detection capability may facilitate determining optimal (above- and below-ground) tissue and sampling time for reliable and reproducible detection of $X$. fastidiosa in peach.

There has been little research done on PPD since the 1980s (French and Crocker 1980; Mizell and French 1987; Wells et al.
1983), although there are numerous publications on $X$. fastidiosa as the cause of previously identified or novel diseases in other specialty crops, including pecans, blueberries, and olives (Cariddi et al. 2014; Chang et al. 2009; Sanderlin and Heyderich-Alger 2000; Saponari et al. 2017), suggesting that $X$. fastidiosa is a real and emerging threat for many crops with a concomitant risk of epidemics, including in peach and other stone fruit. To better understand the development of PPD epidemics, research is needed to provide knowledge, methodology, and short- or long-term solutions to manage the disease. Thus, to aid this process we addressed the following objectives: (i) tested and compared three existing primers for detection of $X$. fastidiosa in phony peach trees; (ii) developed and assessed new $X$. fastidiosa and peach reference gene primers with amplicon size appropriate for both cPCR and qPCR; and (iii) assessed the seasonal changes of $X$. fastidiosa in different tissues using cPCR and qPCR to determine optimal tissue and sampling time for reliable detection of $X$. fastidiosa.

\section{MATERIALS AND METHODS}

Peach trees, samples, and time points. Five PPD affected trees from four peach orchards and four healthy trees from the greenhouse or nursery were sampled in this study. The four orchards and the five PPD trees were Redglobe (RG-R1T6, $\sim 13$ years old when sampled), Julyprince (JP-R1T4 and JP-R2T1, $\sim 7$ years old when sampled), Flavorich (FR-1, $\sim 7$ years old when sampled), and Early Augustprince (EA-1, $\sim 7$ years old when sampled). The former two orchards are research blocks at the USDA-ARS Southeastern Fruit and Nut Research Laboratory, Byron, GA) and the latter two are commercial orchards in Fort Valley, GA. All peach trees were grafted on Guardian (GN) rootstock and received standard orchard management practice for the southeastern United States. The four healthy trees (assumed X. fastidiosa-free based on protection, age and detection) were 1-year-old GN seedlings: GN-1 and GN-2 grown in 20-liter containers in a greenhouse, and GN-3 and GN-4 (recent transplants from the greenhouse) grown in a fenced field nursery. Root samples were collected from the healthy seedlings (one sample per seedling) and the DNA were used as a negative control.

Firstly, eight samples (tissue types) were collected from RGR1T6 (root and leaf), JP-R1T4 (petiole, root, fine root, and stem), FR-1 (root), and EA-1 (root) on 23 September 2015 and were used for initial cPCR detection of $X$. fastidiosa with the three sets of existing primers (Table 1). The resulting gyrB amplicons (from primer pair FXYgyr499 and RXYgyr907) from the four samples of DNA extracted from roots were sequenced to validate identity of $X$. fastidiosa based on sequence alignment on GenBank (Bethesda, $\mathrm{MD})$. The four gyrB-validated samples of DNAs were used as positive controls for $X$. fastidiosa in subsequent PCR.

Secondly, a total of 108 samples were collected from three of the PPD trees (RG-R1T6, JP-R1T4, and JP-R2T1), sampling the root, stem, petiole, and leaf from each tree and taking three replicate samples (root1, root2, root3, and so on) of each tissue type per tree, and with repeated sampling on 20 April, 25 July, and 6 September 2016 , respectively $(3$ trees $\times 4$ tissue types $\times 3$ replicates $\times 3$ times $=$ 108 samples in total). These samples were taken to determine any changes in titer of $X$. fastidios $a$ and differences in ability to detect the pathogen among the four tissue types of the three PPD trees in spring (20 April), summer (25 July), or fall (6 September).

Protocols for tissue preparation, DNA extraction, and quantification. Fresh tissue samples were prepared using the following steps for high-throughput grinding in a GenoGrinder 2000 (SPEX, Metuchen, NJ): (i) approximately $150.0 \mathrm{mg}$ of tissue was placed in a $2 \mathrm{ml}$ microtube (Catalog number 2591L04, Thomas Scientific, Swedesboro, NJ); (ii) two 4.5-mm diameter metal beads were placed in the microtubes, which were put in a 96-well metal block; (iii) the block was stored at $-80^{\circ} \mathrm{C}$ overnight, or until the grinding step; and (iv) the block was placed on the GenoGrinder and 
the tissue ground to a fine powder at 1,000 rpm for $3 \mathrm{~min}$. It is worth noting that microtubes used for grinding must have a wide $\mathrm{V}$-shaped base to allow the grinding beads to move freely. Two beads were used to ensure that no plant tissue stuck to the tube wall, which can occur when only one bead is used. The bark of the roots was stripped (thus processing only the xylem component of the roots) to ensure minimal likelihood of contamination with soil microbes and a higher ratio of $X$. fastidiosa DNA to peach host DNA, that should ensure more consistent PCR performance.

The powdered tissue was stored in a freezer or immediately readied for DNA extraction using an in-house CTAB (cetyl trimethylammonium bromide) protocol. The CTAB extraction buffer contained $100 \mathrm{mM}$ Tris- $\mathrm{HCl}(\mathrm{pH} 8.0), 20 \mathrm{mM}$ EDTA (pH 8.0), $1.4 \mathrm{M} \mathrm{NaCl}, 2 \%$ (wt/vol) CTAB (Amresco, Solon, $\mathrm{OH}$ ) and 2\% (wt/vol) cross-linked polyvinylpyrrolidone (PVP, Acros Organics, $\mathrm{NJ}$ ). The protocol was performed in $2 \mathrm{ml}$ microtubes, as follows: (i) $18 \mu \mathrm{l}$ of 2-mercaptoethanol was added to each tube followed by $900 \mu \mathrm{l}$ of preheated extraction buffer which was mixed, and immediately incubated at $65^{\circ} \mathrm{C}$ in a water bath for $\sim 30 \mathrm{~min}$; (ii) $600 \mu \mathrm{l}$ chloroform was added to each tube that was immediately shaken well and incubated for $10 \mathrm{~min}$; (iii) the tube was centrifuged at $14,000 \mathrm{rpm}$ for $10 \mathrm{~min}$ at room temperature; (iv) $2 \mu \mathrm{lof} 10 \mathrm{mg} / \mathrm{ml}$ RNase A was added to fresh $2.0 \mathrm{ml}$ tubes and the supernatant (the upper phase contains the DNA) from the centrifuged tubes carefully transferred to the new tubes, which were incubated at $37^{\circ} \mathrm{C}$ for $\sim 30 \mathrm{~min}$; (v) $500 \mu \mathrm{l}$ of chloroform was added to these tubes, the mixture was shaken thoroughly, and centrifuged at $14,000 \mathrm{rpm}$ for
10 min at room temperature; (vi) the supernatant was carefully transferred to fresh $1.5 \mathrm{ml}$ tubes; (vii) $1 / 10$ volume of $3 \mathrm{M}$ sodium acetate ( $\mathrm{pH}$ 5.2) and $\sim 2 / 3$ volume of prechilled isopropanol was added and mixed well, and the tube centrifuged at 14,000 rpm for $15 \mathrm{~min}$ at $4^{\circ} \mathrm{C}$ to precipitate the DNA; (viii) the supernatant was carefully discarded and the DNA pellet washed with $500 \mu \mathrm{l}$ of $70 \%$ ethanol, drained, and the pellet air or vacuum dried; and (ix) $200 \mu \mathrm{l}$ of TE was added to dissolve the DNA. A $1 \mu$ l aliquot of the sample was used to check the quality and quantity of the DNA on a $0.8 \%$ agarose gel. The DNA was quantified spectrophotometrically (Nanodrop Products, Wilmington, DE), and stored at $-20^{\circ} \mathrm{C}$ until needed.

In silico characterization of primer sequences. A total of seventeen previously developed and new primers were tested (Table 1). Unless otherwise specified, where the term "primer" is used in this article, it refers to the primer set (i.e., a pair of forward and reverse primers). The first three primers listed in Table 1 were developed for cPCR detection (Rodrigues et al. 2003). The following 14 primers (1 to 14 ) are newly designed in this study and have amplicon sizes suitable for both cPCR and qPCR detection. Of the 14 new primers, primers 1 and 2 (C01Xf-holC and C02Xf-gyrB) and 4 to 10 (C04Xf-petC to C10Xf-ftsY) are based on the $X$. fastidiosa RefSeq coding gene sequences extracted from the UNIPROT database, where multiple entries of these specific genes were annotated with validated gene functions and/or their respective gene sequences identified in complete genomes of different sequenced strains of $X$. fastidiosa. To maximize the

TABLE 1 . The three existing and 14 novel primers used in this study

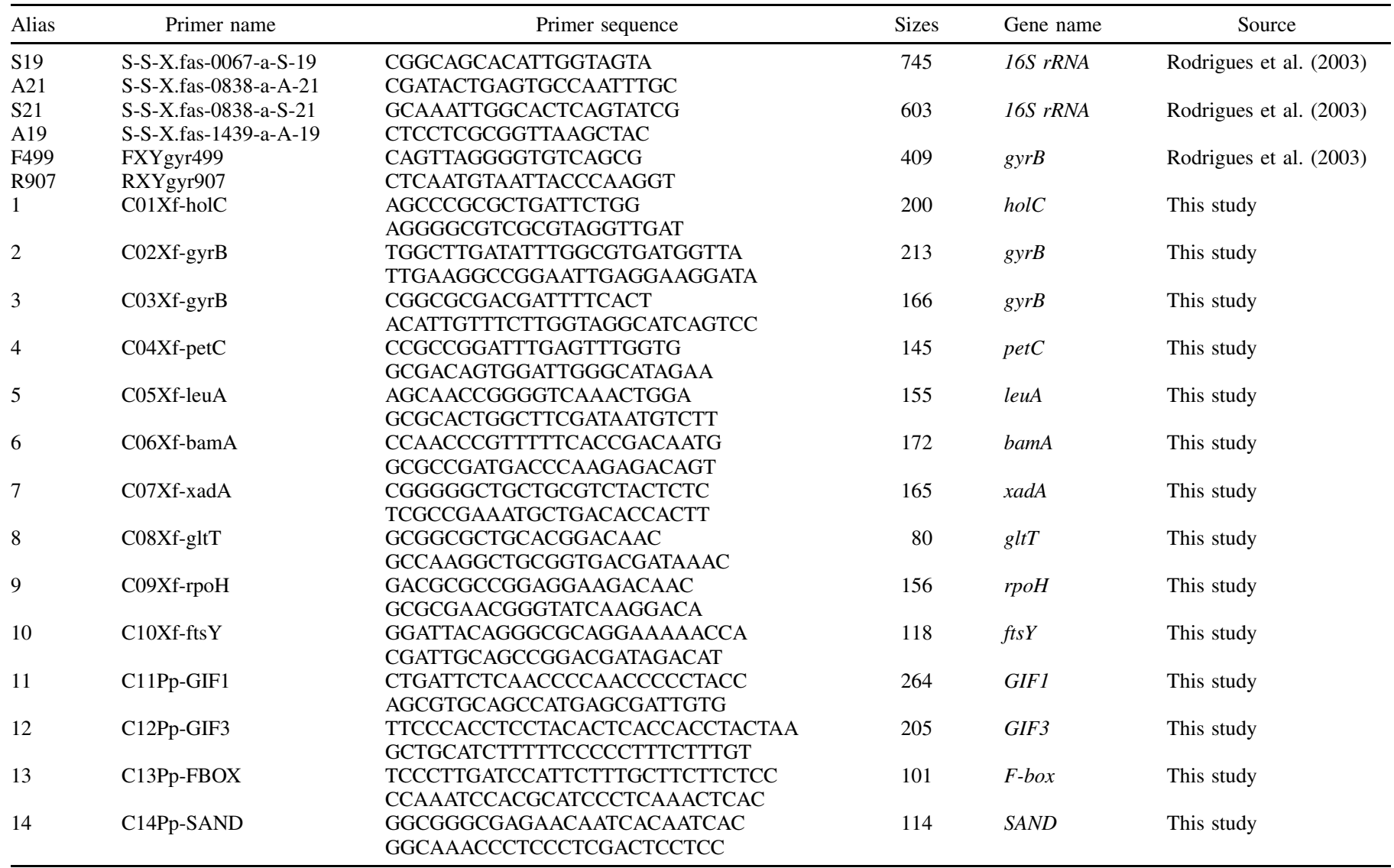

$\mathrm{z}$ The first three sets of primers (the first six aliases) were previously published for detection of Xylella fastidiosa (Rodrigues et al. 2003). Primers with the alias 1 to 10 and 11 to 14 are newly developed primers in this study from X. fastidiosa genes and peach (Prunus persica) reference genes for detection of $X$. fastidiosa and as a DNA extraction control, respectively. The full names of the 14 new primers consisted of a serial number (C01 to C14) plus the initials of Xylella fastidiosa (1 to 10) or Prunus persica (11 to 14) and the gene names. The alias was designated for brevity. The expected genomic amplicon sizes are expressed in base pairs (bp). It is noted that the genomic sequences flanking the peach reference primer 11 and 12 contained an intron of 132 and 119 bp, respectively; so the sizes of their expressed (transcript) amplicons were expected to be 132 and $86 \mathrm{bp}$. These primers were purposely chosen so that the differences could be used for PCR detection of DNA residues in peach RNA samples in future studies. 
likelihood of successful detection of $X$. fastidiosa subsp. multiplex, all the reference gene sequences used for primer design were from accession CP000941 (M12, a strain of X. fastidiosa subsp. multiplex from almond that has been fully sequenced) (Chen et al. 2010), except for the xadA sequence (for primer C07Xf-xadA) which was from accession CP009826 (Pr8x, an unannotated strain isolated from plum). Primer 3 (C03Xf-gyrB) was designed from the sequences of amplicons from phony peach root tissue using primer FXYgyr499/RXYgyr907. Primer 11 to 14 were developed from peach reference genes used as a positive control to ensure that amplification failure was not caused by lack of DNA template or DNA of poor quality. Primer sequences were further used to align to 14 complete genomes and a whole genome sequence (WGS) assembly of $X$. fastidiosa (Table 2), to determine the alignment status and position of these primer sequences and verify the in silico amplicon sizes in these genomes. To assess specificity, the primers were screened against a panel of bacterial species (Supplementary Table S1), including the previously sequenced strain of $X$. fastidiosa subsp. multiplex from almond (M12, GenBank accession CP000941) (Chen et al. 2010).

cPCR and qPCR. cPCR was performed on a 384-well C1000 Touch Thermal Cycler (Bio-Rad, Hercules, CA). The reaction volume was $10 \mu \mathrm{l}$ containing $3.4 \mu \mathrm{l} \mathrm{ddH}_{2} \mathrm{O}, 5 \mu \mathrm{l}$ PCR Master Mix (Promega, Madison, WI), $0.3 \mu \mathrm{l}$ of $10 \mu \mathrm{M}$ forward primer, $0.3 \mu \mathrm{l}$ of $10 \mu \mathrm{M}$ reverse primer, and $1 \mu \mathrm{l}$ DNA ( $\sim 10$ to $100 \mathrm{ng})$. The program consisted of an initial denaturation at $94^{\circ} \mathrm{C}$ for $3 \mathrm{~min}, 30$ cycles of denaturation at $94^{\circ} \mathrm{C}$ for $30 \mathrm{~s}$, annealing at $65^{\circ} \mathrm{C}$ for $30 \mathrm{~s}$, extension at $72^{\circ} \mathrm{C}$ for $1 \mathrm{~min}$, and final extension for $10 \mathrm{~min}$ (Rodrigues et al. 2003). PCR products were resolved on $1.5 \%$ agarose gel, along with a Hi-Lo DNA Marker (50 to 10,000 bp, Bionexus, Oakland, CA). Specificity tests with other bacterial species were performed using only cPCR.

qPCR was performed in a CFX384 Real-time System using $5 \mu \mathrm{l}$ of iQ SYBR Green Supermix (replacing the $5 \mu \mathrm{l}$ of cPCR master mix), following the manufacture's instruction (Bio-Rad, Hercules, CA). CFX Manager was used for real-time data analysis. The qPCR program consisted of an initial denaturation at $95^{\circ} \mathrm{C}$ for $3 \mathrm{~min}, 40$ cycles of denaturation at $94^{\circ} \mathrm{C}$ for $30 \mathrm{~s}$, annealing/extension at $65^{\circ} \mathrm{C}$ for $30 \mathrm{~s}$, followed by a plate read and a melt curve measurement from $65^{\circ} \mathrm{C}$ to $95^{\circ} \mathrm{C}$ with $0.5^{\circ} \mathrm{C}$ increments, holding at each temperature for $5 \mathrm{~s}$. The quantification cycle $(\mathrm{Cq})$ values, melt curve temperatures, melt peaks, and relative fluorescence units (RFU) at the cycle end were calculated and recorded, and relevant charts were generated by the CFX Manager. Based on previously published reports on qPCR detection of $X$. fastidiosa (Francis et al. 2006; Luvisi et al. 2017) and the samples tested in this study, the cutoff Cq value for an X. fastidiosa positive detection was set to 29 . To facilitate the characterization a symbolic rating of $\mathrm{Cq}$ values was developed: "+++++" $(\mathrm{Cq}<=18)$, " ++++ " $(18<\mathrm{Cq}<=21)$, " +++ " $(21<\mathrm{Cq}<=24)$, " ++" $(24<\mathrm{Cq}<=27)$, " + " $(27<\mathrm{Cq}<=29)$ (all positive), "+/-" (29<Cq<=31, unsure), "-" (Cq $>31$, negative), and "N/R" (no reading of $\mathrm{Cq}$ values). The symbolic ratings helped viewing of $\mathrm{Cq}$ values and understanding of the characteristics of the qPCR quantification of $X$. fastidiosa using these primers.

Relative quantification and evaluation of amplification efficiency. A qPCR assay was also performed with $1 \mu$ of DNA $(\sim 200 \mathrm{ng} / \mu \mathrm{l})$ from the JP-R1T4 root3 sample (collected on 6 September 2016) and on a fivefold serial dilution (5x) of the DNA. The approximate concentrations of the serial dilutions were 50, 8 , 1.6, 0.32, and $0.064 \mathrm{ng} / \mu \mathrm{l}$. Primers C03Xf-gyrB, C06Xf-bamA, $\mathrm{C} 10 \mathrm{Xf}-\mathrm{fts} \mathrm{Y}$, and C13Pp-FBOX were used in the assay. The six concentrations of the sample with each of the four primers were used to generate standard curves, estimate the amplification efficiency (E), and determine the relative quantification, following a recently described method (Luvisi et al. 2017). Microsoft EXCEL (Microsoft Inc., Redmond, WA) was used to calculate the regression solution, coefficient of determination $\left(R^{2}\right)$ and the $\mathrm{E}$ value. The $\mathrm{E}$ value was calculated using the equation $\mathrm{E}=\left(10^{(-1 / \text { slope })}-1\right) \times 100$. The standard curve for each primer was estimated by linear regression using the log of the quantity (ng) of the six DNAs plotted on the $\mathrm{x}$-axis and their corresponding $\mathrm{Cq}$ values on the $\mathrm{y}$-axis. The $2^{-\Delta \mathrm{Cq}}$ method [2-(Cq Sample - Cq Reference) $]$ of relative quantification was used to determine the fold change (FC) of the population of $X$. fastidiosa relative to the peach reference gene C13Pp-FBOX (as an internal calibrator), as previously described (Luvisi et al. 2017).

Statistical analysis. Data from the tissue type, primer type, and time of sampling was analyzed using SAS 9.3 (SAS Institute Inc., Cary, NC). The $\mathrm{Cq}$ values measured from the three $X$. fastidiosa primers (C03Xf-gyrB, C06Xf-bamA, and C10Xf-ftsY) and their ratios against the corresponding $\mathrm{Cq}$ values from $\mathrm{C} 13 \mathrm{Pp}$-FBOX, one of the peach reference gene primers, were analyzed using a generalized linear mixed model. The ratios are useful as they can

TABLE 2. In silico analytical specificity of new Xylella fastidiosa primer sequences against $X$. fastidiosa genomes ${ }^{\mathrm{Z}}$

\begin{tabular}{|c|c|c|c|c|c|c|c|c|c|c|c|c|c|c|}
\hline \multirow[b]{2}{*}{ Genome accession } & \multirow[b]{2}{*}{ Host } & \multirow[b]{2}{*}{ Strain } & \multirow[b]{2}{*}{ Subsp. } & \multicolumn{10}{|c|}{ Ten $X$. fastidiosa primers } & \multirow[b]{2}{*}{ Coun } \\
\hline & & & & 1 & 2 & 3 & 4 & 5 & 6 & 7 & 8 & 9 & 10 & \\
\hline CP000941 & Almond & M12 & multiplex & + & + & + & + & + & + & & + & + & + & 9 \\
\hline CP009826 & Plum & $\operatorname{Pr} 8 x$ & & & + & & + & + & + & + & + & + & + & 8 \\
\hline СР009790 & Citrus & $\mathrm{U} 24 \mathrm{D}$ & & & + & & + & + & + & + & + & + & + & 8 \\
\hline AE003849 & Citrus & $9 a 5 c$ & раиса & & + & & + & & + & + & + & + & + & 7 \\
\hline CP009823 & Citrus & J1a12 & & & + & & + & + & + & + & & + & + & 7 \\
\hline СР009829 & Coffer & 3124 & & & + & & + & + & + & + & & + & + & 7 \\
\hline CP009885 & Hibiscus & Hib4 & & & + & & + & + & + & + & & + & + & 7 \\
\hline AE009442 & Grape & Temecula1 & fastidiosa & & & & + & & & & + & + & + & 4 \\
\hline CP001011 & Almond & M23 & fastidiosa & & & & + & & & & + & + & + & 4 \\
\hline СР002165 & Grape & GB514 & fastidiosa & & & & + & & & & + & + & + & 4 \\
\hline СР006696 & Oleander & Ann-1 & sandyi & & & & + & & & & + & + & + & 4 \\
\hline СР006740 & Mulberry & MUL0034 & & & & & + & & + & & & + & + & 4 \\
\hline CP010051 & Citrus & $\mathrm{Fb} 7$ & & & + & & & & & & & & & 1 \\
\hline CP020870 & Olive & De Donno & раиса & & + & & & & & & & & & 1 \\
\hline AVGA01000000 & Red oak & Griffin-1 & multiplex & + & + & + & + & + & + & & + & + & + & 9 \\
\hline Count & & & & 2 & 10 & 2 & 13 & 7 & 9 & 6 & 9 & 13 & 13 & 84 \\
\hline
\end{tabular}

$\mathrm{z}$ The 10 new X. fastidiosa primers (1-10) are C01Xf-holC, C02Xf-gyrB, C03Xf-gyrB, C04Xf-petC, C05Xf-leuA, C06Xf-bamA, C07Xf-xadA, C08Xf-gltT, $\mathrm{C} 09 \mathrm{Xf}-\mathrm{rpoH}$, and C10Xf-ftsY. All the genomes of X. fastidiosa were retrieved from GenBank to perform a local BLAST. Each "+" indicates the forward and reverse sequences of the primer both had a full-length, $100 \%$-nucleotide-identical alignment and expected amplicon size in the corresponding $X$. fastidiosa genome. Thus, these primers with "+" were computationally predicted and expected to produce an amplicon of expected size from the X. fastidiosa genome, and potentially useful for PCR detection of these $X$. fastidiosa genomes/subspecies. A blank indicates all other nucleotide alignment and identity statuses, including that with only one primer sequence fully aligned with $100 \%$ nucleotide identities. 
represent relative $X$. fastidiosa abundance in the tissue types as we did not use pure DNA of $X$. fastidiosa subsp. multiplex to perform absolute quantification in this study. Least squares means were calculated based on Tukey's HSD test to determine differences $(\alpha=0.05)$.

\section{RESULTS}

cPCR detection of $X$. fastidiosa in phony peach trees using three existing primers. Initial PCR detection with the three published primers were performed using the DNA extracted from the root, stem, petiole and leaf tissue from the four peach trees with typical symptoms of PPD (Supplementary Fig. S1). Where amplicons were generated, the size was characteristic of $X$. fastidiosa; however, the presence/absence and intensity varied among the three primers, the samples, and tissue types. Among the four tissue types from JP-R1T4, no observable PCR product was amplified from samples extracted from leaves, stems, or petioles. There was also no observable product amplified from the leaf tissue of RG-R1T6. Amplicons were observed only from root tissue of the four trees with symptoms of PPD, suggesting the root had a much higher titer of $X$. fastidiosa and was therefore more detectable compared with the other tissue types. The detected amplicons were very weak with primers S19/A21 and F499/R907 but much stronger with primers S21/A19, implying the strains of $X$. fastidios $a$ in these phony peach trees might be different to those previously detected by Rodrigues et al. (2003). The four amplicon sequences from primer F499/R907 used for detecting $X$. fastidiosa in root samples from trees RG-R1T6, JP-R1T4, FR, and AE were identical to each other and to GenBank accession DQ022631, a partial gyrB sequence (Supplementary Fig. S2), and had the fewest discrepant nucleotides (only 3 out of $399 \mathrm{bp}$ ) with the corresponding gene sequences of strains M12 and Griffin-1 (both subsp. multiplex), GenBank accessions CP000941 and AVGA01000027, respectively, compared with those from other strains or subspecies (data not shown).

Alignment of the new primer sequences to complete genomes of $\boldsymbol{X}$. fastidiosa. Full alignment of the 10 new primer sequences for detection of $X$. fastidiosa (C01Xf-holC to C10Xf$\mathrm{fts} Y$ ) developed in this study against fourteen complete genomes and one WGS assembly of $X$. fastidiosa varied depending on genome (Table 2). Full alignment of primer sequences with these genomes suggested that the primers should be useful in amplification of the genes and detection of these strains and subspecies. It is worth noting almost all the primer sequences without full alignment had partial alignments in the genomes (data not shown), suggesting PCR amplification could still potentially succeed but was subject to experimental validation, if these primers were to be used in conjunction with these strains and subspecies. Indeed, the degree of primer alignment can facilitate selection of primers to use with different subspecies and strains.

Performance of new primers for $X$. fastidiosa and peach using CPCR and qPCR. Newly designed reference gene primers for both $X$. fastidiosa and peach were first tested using cPCR with two phony peach root DNA samples of contrasting concentrations (Supplementary Fig. S3), i.e., RG-R1T6 root1 (123.1 ng/ $\mu$ l, a high concentration) and root $2(5.2 \mathrm{ng} / \mu \mathrm{l}$, a low concentration), both sampled on Sep 6, 2016. With the RG-R1T6 root1 DNA sample, all primers yielded amplicons of expected size and appropriate intensity. With the RG-R1T6 root2 DNA sample (low concentration), the amplicons were very faint or invisible, suggesting the quantity and/or quality of DNA was insufficient for unambiguous detection. Based on amplicons observed using the RG-R1T6 root2 DNA sample (low concentration), those primers that amplified a weak target product might be slightly more sensitive for detection of $X$. fastidiosa compared with primers with no visible product. In this context, C03Xf-gyrB, C04Xf-petC, C05Xf-leuA, C06Xf-bamA, and C10Xf-ftsY were slightly more sensitive and thus may also be good candidates for $\mathrm{cPCR}$ detection. None of the
10 novel primers produced an amplicon when screened against the panel of species of bacteria other than Xylella, confirming they are highly specific to $X$. fastidiosa.

The qPCR amplification cycles and end products using the fourteen primers were presented for four samples, which included a phony peach root sample (JP-R2T1 root3 sampled on 6 September 2016; Fig. 1A, A1, and A2), a gyrB-validated phony peach root sample as an X. fastidiosa positive control (JP-R1T4 root sampled on 23 September 2015; Fig. 1B), a healthy Guardian root sample as a negative control (GN-2; Fig. $1 \mathrm{C})$, and $\mathrm{ddH}_{2} \mathrm{O}$ as a no template control (Fig. 1D). All qPCR products were also visualized by agarose gel electrophoresis (Fig. 1E and F). The melting temperatures for the primers ranged from 78.5 to $87.5^{\circ} \mathrm{C}$ (Fig. 1A1 and A2), with C01Xf-holC having the highest melting temperature. All the primers amplified the expected targets in the phony peach root and gyrB-validated $X$. fastidiosa positive control samples. Based on the qPCR results in Figure 1 and Supplementary Table S2, most of the X. fastidiosa primers (except C08Xf-gltT) performed well when used in qPCR, based on $\mathrm{Cq}$ values and presence of end products on agarose gel. Primers C04Xf-petC, C05Xf-leuA, and C06Xf-bamA yielded the lowest Cq values, with more consistent band intensities and no visually observable nonspecific products (Fig. 1E and F). C06Xf-bamA had the lowest $\mathrm{Cq}$ value (23.6) with the positive control sample and could be viewed as the best performing primer. C10Xf-ftsY also had a low $\mathrm{Cq}$ value and clear amplicon from both the JP-R2T1 root3 sample and the positive control, however, it had nonspecific products amplified from the healthy negative control which were visually observable on the gel (Fig. 1F, lane 10C) and reflected in its amplification curve (Fig. 1C). Similar results were observed for primer C01Xf-holC (Fig. 1E and C, lane 1C). The nonspecific products, only amplified and visualized with peach DNA (no DNA of $X$. fastidios $a$ present), might increase the likelihood of false positives in qPCR detection (without gel visualization). In this context, it is crucial to validate nonspecific amplification from host DNA in qPCR assay prior to using primers for detection of $X$. fastidiosa in other hosts. The four peach reference gene primers were similar to each other in terms of amplification performance.

Relative quantification and evaluation of amplification efficiency using qPCR. The relative quantification and evaluation of amplification efficiency was performed using DNA from a phony peach root. The $2^{-\Delta \mathrm{Cq}}$ value of the undiluted root DNA sample for C03Xf-gyrB, C06Xf-bamA, and C10Xf-ftsY, relative to C13Pp-FBOX, were 7.16, 8.87, and 7.06, respectively. Standard curves were drawn for three $X$. fastidiosa primers, C03Xf-gyrB (Fig. 2A), C06Xf-bamA (Fig. 2B), C10Xf-ftsY (Fig. 2C), and for one peach reference gene primer (the host DNA extraction control and internal calibrator), C13Pp-FBOX (Fig. 2D). The charts were based on the log of the quantity of six serial dilutions of DNA from the phony peach root sample (x-axis) and the corresponding $\mathrm{Cq}$ values (y-axis), showing a nearly perfect linear relationship for each primer $\left(R^{2}=0.9985,0.9986,0.9976\right.$, and 0.9964 , respectively). The primer E values were $103.1,97.8,98.1$, and $108.0 \%$, respectively, suggesting the amplification efficiency of the primers was high. With the last two DNA dilutions $(0.32$ and $0.064 \mathrm{ng})$, all three $X$. fastidiosa primers yielded Cq values of approximately 27 and 30, with the amplicons visible and almost invisible on an agarose gel, respectively (data not shown). The results suggested that the lowest concentration of $X$. fastidiosa DNA needed for detection of $X$. fastidiosa using qPCR (and/or cPCR) likely falls within the range of the final two dilutions from the root sample (0.064 to $0.32 \mathrm{ng}$ ), although the ratio of $X$. fastidiosa to host DNA is critical in determining the absolute amount of $X$. fastidiosa DNA present in a mixed sample and thus affects the detection sensitivity.

Comparison of primer, tissue type and sample time for detecting $\boldsymbol{X}$. fastidiosa in phony peach trees. All the 108 samples collected on 20 April, 25 July, and 6 September 2016, respectively, were subjected to $\mathrm{cPCR}$ and $\mathrm{qPCR}$ detection. $\mathrm{cPCR}$ 
was performed with only C06Xf-bamA (Fig. 3A, C, and E), the best performing primer for detecting $X$. fastidiosa in phony peach tissues, and C13Pp-FBOX (Fig. 3B, D, and F), a peach reference gene primer as a DNA extraction control to ensure DNA extraction was sufficient and of good quality. As shown in the gel electrophoretic images, cPCR using C06Xf-BamA resulted in consistently strong amplicons only from root samples, but not from samples of the other three tissues (only a few yielded weak visible products) (Fig. 3A, C, and E). Reference primer C13Pp-FBOX produced amplicons from most DNAs, regardless of tissue type (Fig. 3B, D, and F). Thus, only samples extracted from roots yielded strong amplicons of expected sizes by C06Xf-bamA.
However, four root samples, i.e., lane 15 in Figure $3 \mathrm{~A}$ and B, and lanes 1, 3, and 15 in Figure 3C and D, contained no detectable DNA of $X$. fastidiosa. The first three samples had failed amplification with peach primer C13Pp-FBOX, indicating that the quantity and/ or quality of the DNAs in these three samples was too low to amplify and detect. Only the PCR with the last sample resulted in successful amplification of peach DNA, indicating that DNA of $X$. fastidiosa was insufficient for amplification and detection in that sample. The cPCR results suggested that sampling time did not affect detectability of $X$. fastidiosa in these tissue types in phony peach trees, although band intensity varied slightly among root samples from the same trees on different sample dates.
A

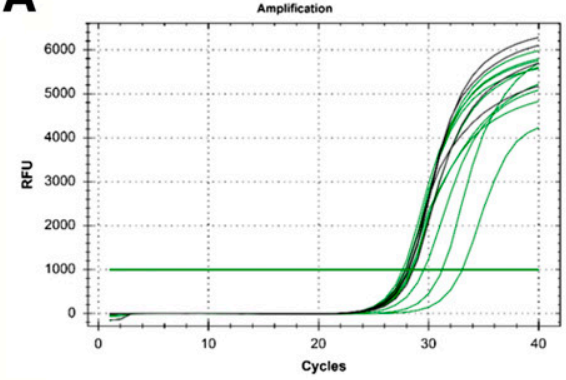

B

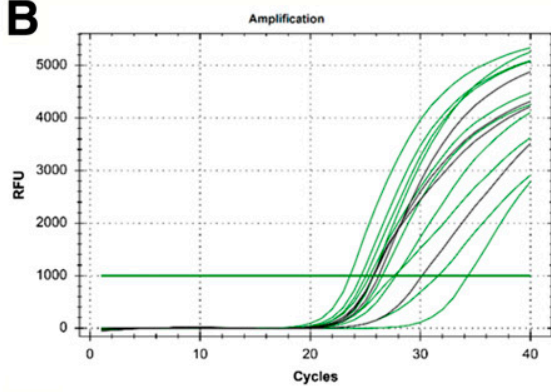

A1

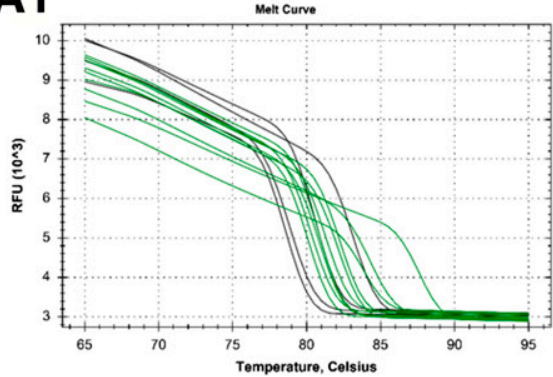

C

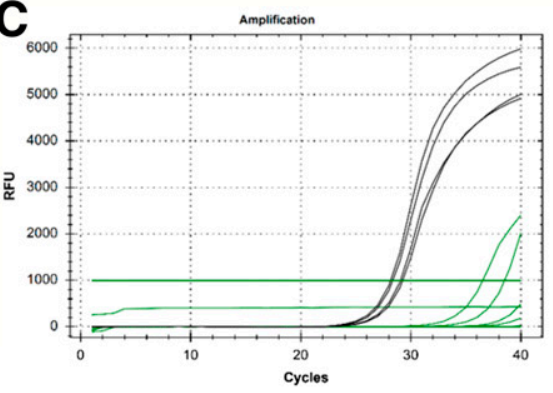

A2

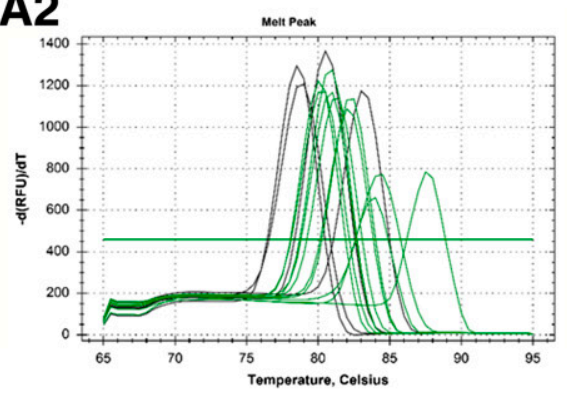

D

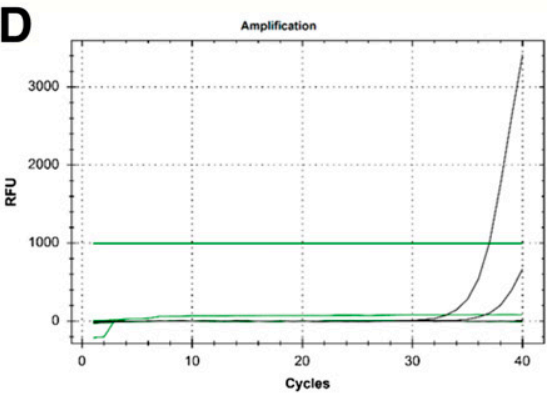

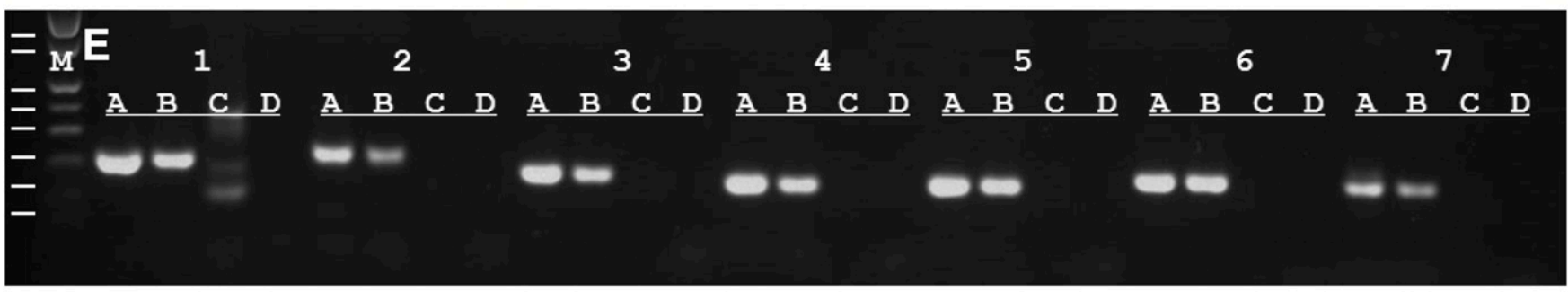

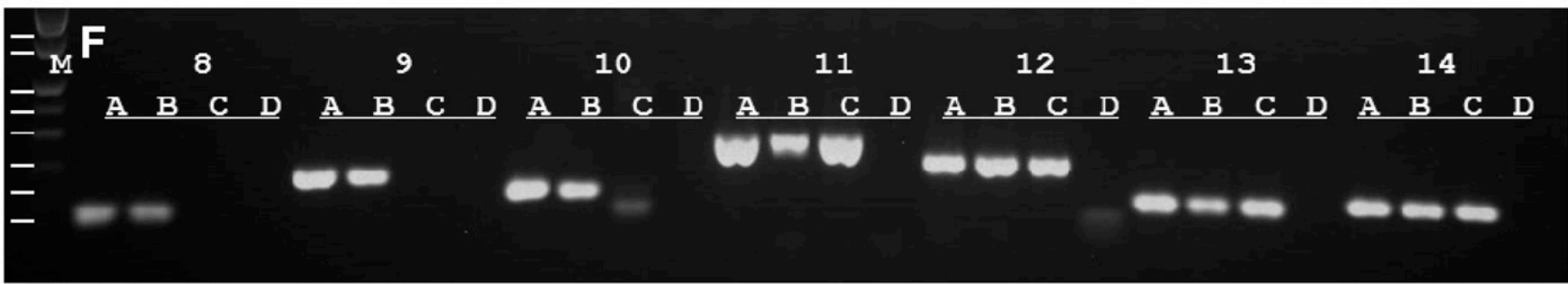

Fig. 1. A to D, Quantitative PCR (qPCR) amplification cycles and $\mathbf{E}$ and $\mathbf{F}$, products on agarose gels for the 10 new Xylella fastidiosa primers (1 to 10) and four new peach (Prunus persica) reference gene primers (11 to 14) (Table 1). The samples used were DNA from root of phony peach tree JP-R2T1 showing the A, amplification, A1, melt curve, and A2, melt peak, an B, X. fastidiosa positive gyrB-validated sample from root of phony peach tree JP-R1T4 as an X. fastidiosa positive control, C, DNA extracted from root of a healthy Guardian seedling (GN-2) as a negative control, and $\mathbf{D}$, $\mathrm{ddH}_{2} \mathrm{O}$ as a nontemplate control. A to $\mathbf{D}$, The $X$. fastidiosa primers are depicted in gray, and the four peach primers are depicted in black. $\mathbf{E}$ and $\mathbf{F}$, The primer aliases 1 to 14 for each of the samples $\mathbf{A}$ to $\mathbf{D}$ are indicated, respectively. The expected amplicon sizes in base pairs are given in the parentheses following the 14 primer names: $\mathrm{C} 01 \mathrm{Xf}-\mathrm{holC}$ (200), C02Xf-gyrB (213), C03Xf-gyrB (166), C04Xf-petC (145), C05Xf-leuA (155), C06Xf-bamA (172), C07Xf-xadA (165), C08Xf-gltT (80), C09Xf-rpoH (156), C10Xf-ftsY (118), C11Pp-GIF1 (264), C12Pp-GIF3 (205), C13Pp-FBOX (101), and C14Pp-SAND (114). Three primers, C01Xf-holC, C10Xf-ftsY, and C12Pp-GIF3, amplified nonspecific products that were visible on gels (lane 1C in E, lane 10C and 12D in F, respectively), displayed in amplification curves (the two higher gray curves in $\mathrm{C}$ and the higher black curve in D, respectively, all reaching above the threshold line of 1,000 relative fluorescence units [RFU]), and yielded quantification cycle (Cq) values $(36.5,38.5$, and 37.0, respectively). No visible bands or Cq values were produced for the other two lower gray curves in C (from primers C04Xf-petC and C08Xf-gltT) and the lower black curve in D (from primer C11Pp-GIF1) that were all below the threshold line of 1,000 RFU. Nonspecific amplification might increase the likelihood of false positives using qPCR detection (without gel visualization). M, DNA marker (white dashes along the size marker from the bottom to top are 50,100, 200, 300, 400,500, 750, and 1,000 bp, respectively). 
In addition to primer C06Xf-bamA and C13Pp-FBOX, qPCR was also performed with $\mathrm{C} 03 \mathrm{Xf}$-gyrB (from the gyrB-validated amplicon sequence) and C10Xf-ftsY (which had a low Cq value but nonspecific products) for comparison with C06Xf-bamA, using the same samples collected on 20 April, 25 July, and 6 September 2016, respectively (Supplementary Table S3). Similar to the results observed from the cPCR, qPCR generated consistent, reliable detection only with the samples from root tissues (X. fastidiosa positives based on $\mathrm{Cq}$ values); samples from other tissue types were not consistent. Indeed, the samples from leaves, petioles and stems were not reliable for detection of $X$. fastidiosa, as all of them yielded $\mathrm{Cq}$ values in the ranges of uncertain calls, or less than the cut-off for clear $X$. fastidiosa positive samples, which was similar to the pattern found when using $\mathrm{cPCR}$ with primer C06Xf-bamA and agarose gel electrophoresis (Fig. 3E). The means of $\mathrm{Cq}$ values from all stem, petiole, or leaf samples using C03Xf-gyrB, CX06Xf-bamA, or C10Xf-ftsY were numerically similar, although those samples from petioles had slightly lower values (likely due to higher titer) compared with those from the stem or leaf. In contrast, the peach control primer yielded an average of 17.73 from all leaf DNA samples. The results from samples collected on 20 April and 25 July 2016 were very similar with Cq values for reliable positive detection observed only for DNA from roots.

Variation in the $\mathrm{Cq}$ values among the tissue types might reflect the differences in actual titer of $X$. fastidios $a$ of the samples containing a mixture of DNA from $X$. fastidios $a$ and the peach host. The quantity of $X$. fastidiosa DNA from the stem, petiole, and leaf tissues was similar to each other, based on their average $\mathrm{Cq}$ values (i.e., 30.89 for stem, 31.17 for petiole, and 30.95 for leaf, Table 3), and was approximately $5^{5}$ times lower than that from the root tissue used for the relative quantification (Fig. 2). This can be deduced because the
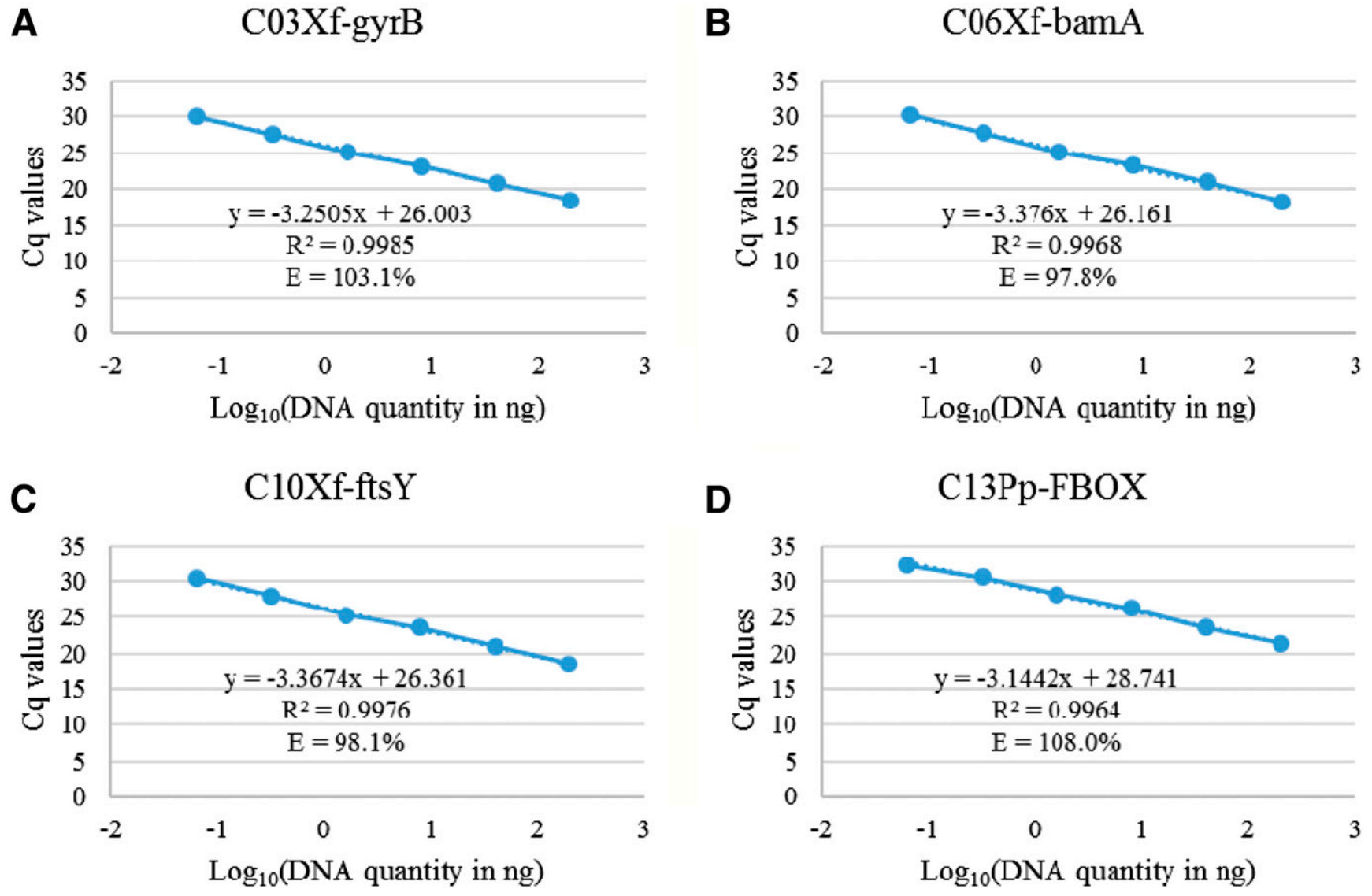

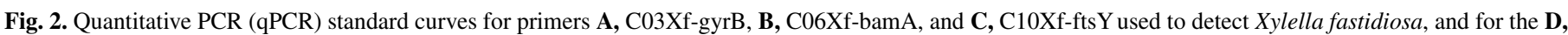

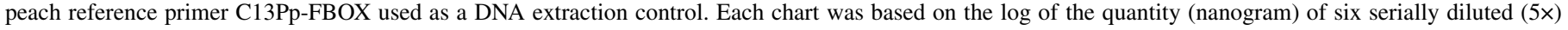

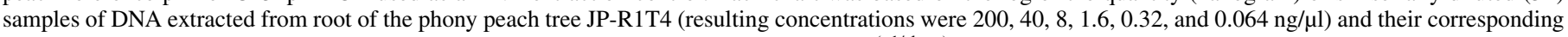

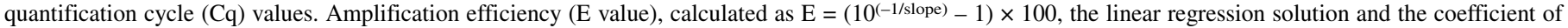
determination $\left(R^{2}\right.$ value) for each primer are indicated. 
and C03Xf-gyrB. Primer C03Xf-gyrB had numerically the lowest $\mathrm{Cq}$ value. The primer might be slightly more sensitive for detection of X. fastidiosa subsp. multiplex partly because this primer sequence was derived from the amplicon sequence acquired from local PPD trees, and thus had the least likelihood of discrepant nucleotides. The Cq value was statistically the same on 20 April 2016 (spring) and 6 September 2016 (fall). Although on 25 July 2016 (summer) there was a significantly lower Cq value compared with the spring, it was a numerically small difference, and not different to the Cq value in the fall. Such differences are not big enough to make the detection sensitivity at one of the three sampling time points notably better compared with the other. However, the mean $\mathrm{Cq}$ value from root tissue was significantly lower compared with that from the three other tissue types; indeed, root was the only source tissue type resulting in reliable cPCR and qPCR detection of $X$. fastidios $a$ at all three sample times. The mean $\mathrm{Cq}$ values for the interacting main effects are not straightforward to interpret, especially on account of the generally very small numerical differences.

\section{DISCUSSION}

In this study we designed and screened 10 novel $X$. fastidiosa primers to detect $X$. fastidiosa in peach and most showed reliable cPCR and/or qPCR amplification and detection of the pathogen in phony peach root samples. Primer C06Xf-bamA was extensively tested and appeared to be a reliable, specific, and sensitive primer for both cPCR and qPCR compared with the other primers screened. PCR-based methods have been invaluable for monitoring and studying the distribution and spread of $X$. fastidiosa in specific hosts and in crop situations (Cao et al. 2011; Groves et al. 2005; Harper et al. 2010; Ledbetter and Rogers 2009). These primers (e.g., C06Xf-bamA and C13Pp-FBOX) should be useful for monitoring
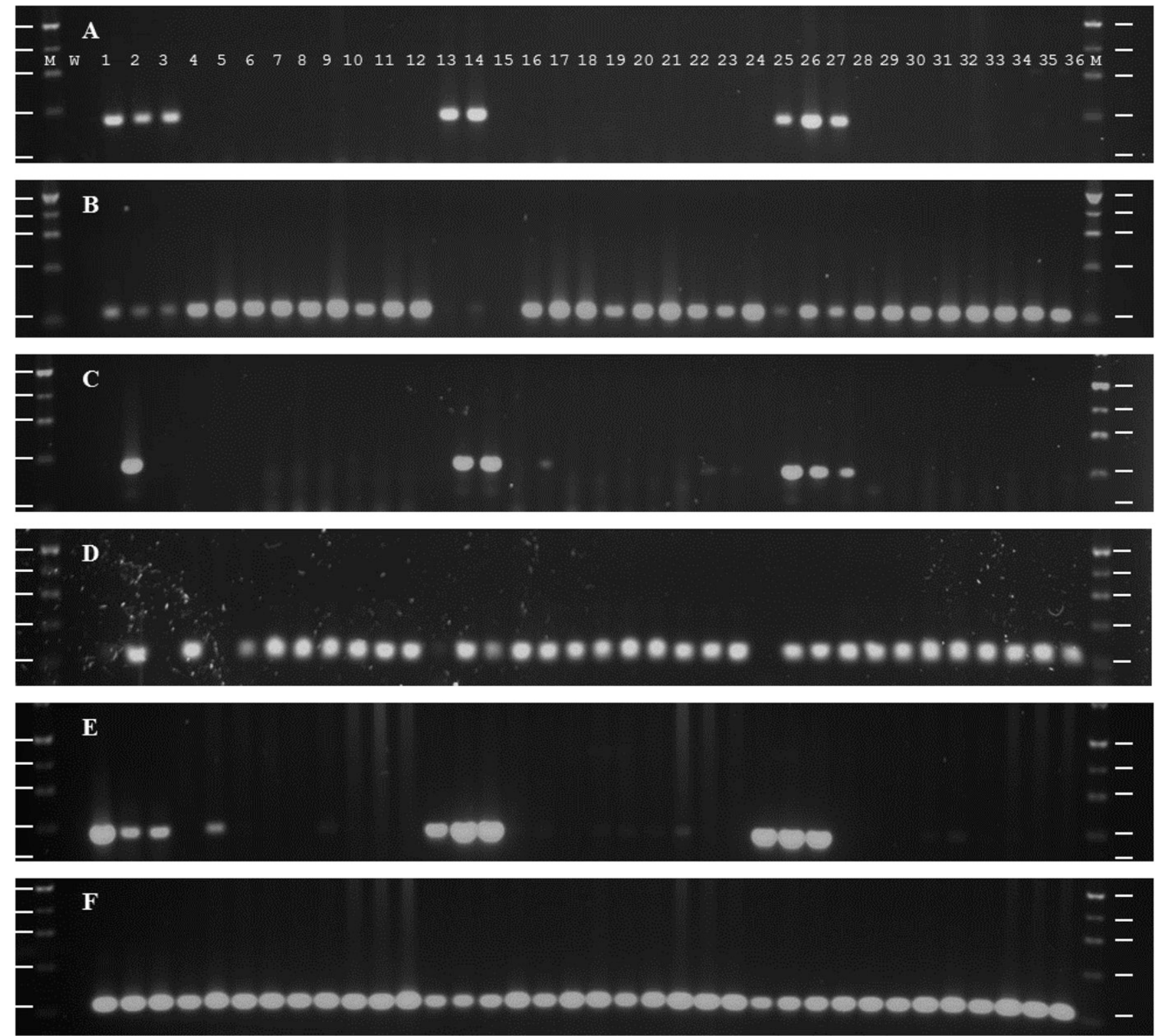

Fig. 3. Conventional PCR products amplified by primer C06Xf-bamA (A, C, and E, to detect Xylella fastidiosa and C13Pp-FBOX and B, D, and F, to amplify the peach gene and serve as a DNA extraction control). The 36 samples represented were collected on A and B, 20 April 2016, C and D, 25 July 2016, and $\mathbf{E}$ and F, 6 September 2016, respectively. The lane number 1 to 12 were sampled from tree RG-R1T6 in the Redglobe orchard, lanes 13 to 24 , and lanes 25 to 36 from trees JPR1T4, and JP-R2T1 in the Julyprince orchard, respectively. The samples from each tree were ordered by root, stem, petiole, and leaf tissue type, respectively, with three samples of each tissue type. Only the samples of DNA from root yielded strong amplicons, but failures in root DNAs in lanes A15, C1, C3, and C13 with both C06Xf-bamA and C13Pp-FBOX suggested that the quantity and/or quality of these DNA samples were suboptimal. M, DNA marker (white dashes alongside the marker from the bottom to top are 100, 200, 300, 400, and $500 \mathrm{bp}$, respectively). W, $\mathrm{ddH}_{2} \mathrm{O}$. 
$X$. fastidiosa in peach orchards in both symptomatic and asymptomatic trees. Furthermore, these primers have also been used successfully to detect $X$. fastidiosa in symptomatic pecan trees in GA (C. Chen and C. Bock, personal observations). Primers C03XfgyrB and C10Xf-ftsY had clear and reliable cPCR amplicons detecting $X$. fastidiosa in roots of phony peach, but the $\mathrm{Cq}$ values with the same samples were generally higher compared with those of primer C06Xf-bamA. It should be noted that primers C01XfholC and C10Xf-ftsY yielded gel-visible nonspecific qPCR products from healthy control samples (Fig. 1E and F), even though the $\mathrm{Cq}$ values from the nonspecific qPCR products were much higher (36.5 and 38.5, respectively), compared with those from the PPD sample and positive control. The nonspecific products could complicate qPCR detection and might increase the likelihood of false positives when using qPCR with these primers (without gel electrophoresis visualization the nonspecificity of the qPCR products would not be known as a $\mathrm{Cq}$ value is generated regardless of the specificity of the amplicons). PCR is a complicated process with many factors that can lead to specific and/or nonspecific amplification. Even though no nonspecific bands were visualized from the remaining primers screened, qPCR-detectable nonspecific amplification from healthy negative control samples might take place yielding $\mathrm{Cq}$ values in the range slightly higher than or similar to those from nonroot phony peach tissues. The similarity in $\mathrm{Cq}$ values prevented calling nonroot phony peach tissue samples positive even though the trees were known to be positive based on the root samples. In this context, it appears necessary to further optimize PCR conditions for these primers; and if nonspecific amplification from host DNA can be eliminated (i.e., no or very high $\mathrm{Cq}$ value for healthy negative controls), qPCR detection of $X$. fastidiosa in nonroot tissues with these primers might be possible. These contentions are supported by the fact that most of the nonroot tissues generated $\mathrm{Cq}$ values in the uncertain range (i.e., 30.89 for stem, 31.17 for petiole, 30.95 for leaf on average, Table 3) that were just too high to be confidently determined as positive, when compared with those from the healthy negative controls. Therefore, improvement of the qPCR assay with these novel primers might allow $\mathrm{Cq}$ values arising from amplification from low quantities of DNA of $X$. fastidiosa in peach stem, petiole, and leaf tissues (approximately $5^{5}$ times lower than most root tissues) to be distinguished from healthy negative controls and thus scored as definite positives. We did not isolate the bacterium directly and it was not possible to quantify the actual concentration of $X$. fastidiosa in a mix of $X$. fastidiosa and host DNA. Pure DNA of $X$. fastidiosa from peach is needed for absolute quantification (Francis et al. 2006; Oliveira et al. 2002). In the future this will be useful for estimates of bacterial counts for studies characterizing the distribution of $X$. fastidiosa in entire trees, monitoring the seasonal fluctuation and postinfection movement of $X$. fastidios $a$ in different host tissues, and facilitating host-pathogen interaction studies using resistant/tolerant peach germplasm. A further observation to note is that primer C08Xf-gltT behave somewhat differently to the other primers in the qPCR, most likely due to the small size ( $80 \mathrm{bp}$ ) and high GC content $(\sim 65 \%)$ of its amplicon.

We also found that detection sensitivity varied with tissue types and root was the only tissue to sample for reliable PCR detection of $X$. fastidiosa from infected peach trees, regardless of source tree, primer, sampling time, or PCR methods. This is congruent with two previous reports describing the greatest bacterial counts were in roots (Aldrich et al. 1992; Wells et al. 1980). There were higher bacterial counts with more uniform distribution in roots from symptomatic phony peach trees compared with those from asymptomatic trees, further emphasizing the inherent difficulty sampling testable tissues to detect $X$. fastidiosa in asymptomatic peach trees. The detectability of infected but asymptomatic peach trees was highly dependent on the root sample size per tree, and insufficient samples per tree would increase the likelihood of a negative and result in an underestimation of the incidence of infected trees (Aldrich et al. 1992). One explanation for the reliability in detecting $X$. fastidios $a$ only in the roots could be that

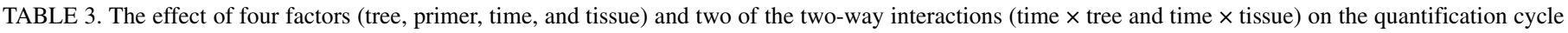

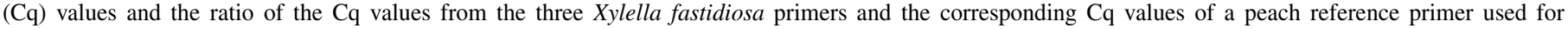
quantitative PCR detection of $X$. fastidiosa in phony peach trees ${ }^{z}$

\begin{tabular}{|c|c|c|c|c|c|c|c|c|c|}
\hline Factors & $\mathrm{Cq}$ & SE & Ratio & SE & Interactions & $\mathrm{Cq}$ & SE & Ratio & SE \\
\hline \multicolumn{10}{|l|}{ Time $\times$ tree } \\
\hline \multicolumn{10}{|l|}{ Tree } \\
\hline RG-R1T6 & 29.80 & $0.21 \mathrm{a}$ & 1.39 & $0.01 \mathrm{a}$ & Apr $20 \times$ RG-R1T6 & 29.75 & $0.35 \mathrm{ab}$ & 1.31 & $0.01 \mathrm{~d}$ \\
\hline JP-R1T4 & 28.55 & $0.20 \mathrm{~b}$ & 1.36 & $0.01 \mathrm{~b}$ & Jul $25 \times$ RG-R1T6 & 29.35 & $0.40 \mathrm{abc}$ & 1.39 & $0.01 \mathrm{bc}$ \\
\hline \multirow[t]{3}{*}{ JP-R2T1 } & 28.58 & $0.21 b$ & 1.37 & $0.01 \mathrm{ab}$ & Sep $6 \times$ RG-R1T6 & 30.30 & $0.36 \mathrm{a}$ & 1.47 & $0.01 \mathrm{a}$ \\
\hline & & & & & Apr $20 \times$ JP-R1T4 & 29.41 & $0.35 \mathrm{abc}$ & 1.29 & $0.01 \mathrm{~d}$ \\
\hline & & & & & Jul $25 \times$ JP-R1T4 & 28.08 & $0.35 \mathrm{c}$ & 1.38 & $0.01 \mathrm{bc}$ \\
\hline Primer & & & & & Sep $6 \times$ JP-R1T4 & 28.16 & $0.35 \mathrm{c}$ & 1.41 & $0.01 \mathrm{~b}$ \\
\hline C03Xf-gyrB & 28.55 & $0.21 b$ & 1.36 & $0.01 b$ & Apr $20 \times$ JP-R2T1 & 28.95 & $0.35 \mathrm{abc}$ & 1.34 & $0.01 \mathrm{~cd}$ \\
\hline C06Xf-bamA & 28.78 & $0.21 b$ & 1.36 & $0.01 b$ & Jul 25 × JP-R2T1 & 28.31 & $0.37 \mathrm{bc}$ & 1.35 & $0.01 \mathrm{~cd}$ \\
\hline C10Xf-ftsY & 29.60 & $0.21 \mathrm{a}$ & 1.40 & $0.01 \mathrm{a}$ & Sep $6 \times$ JP-R2T1 & 28.48 & $0.35 b c$ & 1.41 & $0.01 \mathrm{~b}$ \\
\hline \multicolumn{10}{|l|}{ Time $\times$ tissue } \\
\hline Time & & & & & Apr $20 \times$ root & 24.79 & $0.41 \mathrm{c}$ & 0.99 & $0.01 \mathrm{f}$ \\
\hline Apr 20 & 29.37 & $0.20 \mathrm{a}$ & 1.31 & $0.01 \mathrm{c}$ & Jul $25 \times$ root & 22.23 & $0.49 \mathrm{~d}$ & 0.94 & $0.02 \mathrm{fg}$ \\
\hline Jul 25 & 28.58 & $0.22 b$ & 1.37 & $0.01 \mathrm{~b}$ & Sep $6 \times$ root & 21.68 & $0.41 \mathrm{~d}$ & 0.92 & $0.01 \mathrm{~g}$ \\
\hline \multirow[t]{3}{*}{ Sep 6} & 28.98 & $0.21 \mathrm{ab}$ & 1.43 & $0.01 \mathrm{a}$ & Apr $20 \times$ stem & 30.69 & $0.41 \mathrm{ab}$ & 1.44 & $0.01 \mathrm{~d}$ \\
\hline & & & & & Jul $25 \times$ stem & 30.44 & $0.41 \mathrm{ab}$ & 1.45 & $0.01 \mathrm{~cd}$ \\
\hline & & & & & Sep $6 \times$ stem & 31.55 & $0.41 \mathrm{a}$ & 1.48 & $0.01 \mathrm{~cd}$ \\
\hline Tissue & & & & & Apr $20 \times$ petiole & 30.81 & $0.41 \mathrm{ab}$ & 1.47 & $0.01 \mathrm{~cd}$ \\
\hline Root & 22.90 & $0.24 b$ & 0.95 & $0.01 \mathrm{c}$ & Jul $25 \times$ petiole & 32.03 & $0.41 \mathrm{a}$ & 1.61 & $0.01 \mathrm{~b}$ \\
\hline Stem & 30.89 & $0.25 \mathrm{a}$ & 1.46 & $0.01 b$ & Sep $6 \times$ petiole & 30.66 & $0.41 \mathrm{ab}$ & 1.52 & $0.01 \mathrm{c}$ \\
\hline Petiole & 31.17 & $0.24 \mathrm{a}$ & 1.53 & $0.01 \mathrm{a}$ & Apr $20 \times$ leaf & 31.19 & $0.41 \mathrm{ab}$ & 1.35 & $0.01 \mathrm{e}$ \\
\hline \multirow[t]{2}{*}{ Leaf } & 30.95 & $0.24 \mathrm{a}$ & 1.55 & $0.01 \mathrm{a}$ & Jul $25 \times$ leaf & 29.61 & $0.41 b$ & 1.50 & $0.01 \mathrm{~cd}$ \\
\hline & & & & & Sep $6 \times$ leaf & 32.03 & $0.42 \mathrm{a}$ & 1.81 & $0.02 \mathrm{a}$ \\
\hline
\end{tabular}

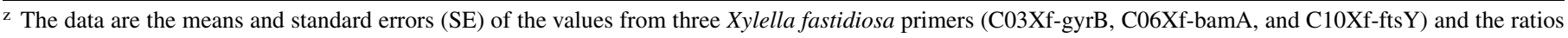
of the $\mathrm{Cq}$ values from the three $X$. fastidiosa primers and the corresponding $\mathrm{Cq}$ values from one peach reference primer $\mathrm{C} 13 \mathrm{Pp}-\mathrm{FBOX}$, respectively, under each of the four factors (tree, primer, time, and tissue) and of the two most important interactions (time $\times$ tree and time $\times$ tissue). For brevity, time $=$ sampling time, tissue $=$ tissue type, $\mathrm{RG}=$ Redglobe, and JP = Julyprince. Data were analyzed using a generalized linear mixed model calculating least square means with a Tukey's HSD adjustment. Least square means with the same letter are not significantly different $(\alpha=0.05)$. All samples of DNA were extracted from roots with the bark removed. 
the ratio of $X$. fastidiosa to host DNA is substantially higher in the roots compared with other tissue types. However, roots tend to be the most difficult organ to sample from a practical point of view, which could create logistical issues. The tissue type and sampling time as an important factor for the reliable detection of $X$. fastidiosa has been noted in previous studies (Chen et al. 2008; Wells et al. 1980). In other hosts, reliable detection was possible using sap extracted from shoots, leaves or branches (Chen et al. 2008; Francis et al. 2006; Minsavage et al. 1994). We did not notice much difference in detection of $X$. fastidiosa based on $\mathrm{Cq}$ values using samples taken in the spring (April), summer (July), or early fall (September). But samples taken in spring had numerically the lowest $\mathrm{Cq}$ value, indicating a higher titer of bacteria. Wells et al. (1980) had previously observed highest counts of the Rickettsia-like Xylella bacteria in the spring and summer in phony peach trees. We also note that the $\mathrm{Cq}$ ratio, which corrects for proportion of total DNA, was lowest in early spring, intermediate in the summer, and highest in early fall, indicating a similar trend to that observed by Wells et al. (1980). Similar seasonal sensitivity in detection have been observed in almond (Chen et al. 2008), and highest counts of the bacteria were observed in the summer and autumn in grape with Pierce's disease (Hopkins and Thompson 1984). Seasonal within-peach tree dynamics of $X$. fastidiosa remain to be fully characterized and the primers developed should be useful in this endeavor.

We had observed that failure or inconsistency in PCR detection of $X$. fastidiosa in root samples appeared to be associated with how the root sample was processed prior to DNA extraction: extraction from the entire root tissue (including the bark) resulted in less consistent detention (data not shown). Therefore, in this study, all root samples had the bark removed prior to DNA extraction. The cause of frequent failure in detection from the entire root tissue remains unclear but might be due to interference of the PCR reaction with DNA from other soil-borne microbes and/or other inhibitory substances from the bark. Most of the cells in the core of the root (with the bark removed) are dead and contain proportionately less peach DNA compared with that in the other tissue types, particularly leaves. Regardless, $X$. fastidiosa appears to be present at a higher titer in the root based on our experimental data and previous observations (Wells et al. 1980). Distribution of the bacterium in peach may be a reason why $X$. fastidiosa-infected peach trees never develop the typical scorch of most other $X$. fastidiosainfected hosts (Janse and Obradovic 2010), where water deficit due to xylem clogging may result in symptom development (Choi et al. 2013). To fully explain these observations and test these hypotheses, more research is needed on the host-pathogen interaction and quantification and distribution of $X$. fastidiosa in phony peach trees.

In conclusion, these primers are additional resources for detection of $X$. fastidiosa in peach and other host plants, adding to those previously published (Baldi and La Porta 2017). C06XfbamA and C03Xf-gyrB are two extensively tested primers suitable for reliable detection of $X$. fastidiosa subsp. multiplex using both cPCR and qPCR. Samples of root (without the bark) were the only reliable tissue source for confirmative $\mathrm{CPCR}$ and $\mathrm{qPCR}$ detection of $X$. fastidiosa in phony peach trees. Further optimization of PCR conditions with the different primers to eliminate nonspecific amplification and yield no reading of $\mathrm{Cq}$ value from healthy negative controls might make qPCR detection of $X$. fastidiosa in nonroot phony peach tissues possible. Accurate detection and quantification of $X$. fastidiosa is needed for epidemiological studies, large-scale surveys, and assessment of PPD-resistant peach and other Prunus genotypes for breeding purposes.

\section{ACKNOWLEDGMENTS}

We thank M. Zhang, B. Blackburn, and M. Hotchkiss at the USDA-ARSSEFTNRL for their technical expertise and help, L. De La Fuente, Auburn
University, AL, for providing additional samples of bacterial species for the specificity tests, and J. Chen at the USDA-ARS-SJVASC in Parlier, CA for providing a sample of DNA of the characterized strain of $X$. fastidiosa subsp. multiplex from almond that has been fully sequenced (M12, GenBank accession CP000941).

\section{LITERATURE CITED}

Aldrich, J. H., Gould, A. B., and Martin, F. G. 1992. Distribution of Xylella Fastidiosa within roots of peach. Plant Dis. 76:885-888.

Almeida, R. P. P., and Nunney, L. 2015. How do plant diseases caused by Xylella fastidiosa emerge? Plant Dis. 99:1457-1467.

Baldi, P., and La Porta, N. 2017. Xylella fastidiosa: Host range and advance in molecular identification techniques. Front. Plant Sci. 8:1-22.

Banks, D., Albibi, R., Chen, J. C., Lamikanra, O., Jarret, R. L., and Smith, B. J. 1999. Specific detection of Xylella fastidiosa Pierce's disease strains. Curr. Microbiol. 39:85-88.

Cao, T., Connell, J. H., Wilhelm, M., and Kirkpatrick, B. C. 2011. Influence of inoculation date on the colonization of Xylella fastidiosa and the persistence of almond leaf scorch disease among almond cultivars. Plant Dis. 95: 158-165.

Cariddi, C., Saponari, M., Boscia, D., De Stradis, A., Loconsole, G., Nigro, F., Porcelli, F., Potere, O., and Martelli, G. P. 2014. Isolation of a Xylella fastidiosa strain infecting olive and oleander in Apulia, Italy. J. Plant Pathol. 96:425-429.

Chang, C. J., Donaldson, R., Brannen, P., Krewer, G., and Boland, R. 2009. Bacterial leaf scorch, a new blueberry disease caused by Xylella fastidiosa. HortScience 44:413-417.

Chen, J., Huang, H., Chang, C. J., and Stenger, D. C. 2013. Draft genome sequence of Xylella fastidiosa subsp. multiplex strain Griffin-1 from Quercus rubra in Georgia. Genome Announc. 1:e00756-13.

Chen, J., Livingston, S., Groves, R., and Civerolo, E. L. 2008. High throughput PCR detection of Xylella fastidiosa directly from almond tissues. J. Microbiol. Methods 73:57-61.

Chen, J., Xie, G., Han, S., Chertkov, O., Sims, D., and Civerolo, E. L. 2010. Whole genome sequences of two Xylella fastidiosa strains (M12 and M23) causing almond leaf scorch disease in California. J. Bacteriol. 192: 4534.

Choi, H. K., Iandolino, A., da Silva, F. G., and Cook, D. R. 2013. Water deficit modulates the response of Vitis vinifera to the Pierce's disease pathogen Xylella fastidiosa. Mol. Plant-Microbe Interact. 26:643-657.

Cornara, D., Cavalieri, V., Dongiovanni, C., Altamura, G., Palmisano, F., Bosco, D., Porcelli, F., Almeida, R. P. P., and Saponari, M. 2016. Transmission of Xylella fastidiosa by naturally infected Philaenus spumarius (Hemiptera, Aphrophoridae) to different host plants. J. Appl. Entomol. 141: 80-87.

Cornara, D., Saponari, M., Zeilinger, A. R., de Stradis, A., Boscia, D., Loconsole, G., Bosco, D., Martelli, G. P., Almeida, R. P. P., and Porcelli, F. 2017. Spittlebugs as vectors of Xylella fastidiosa in olive orchards in Italy. J. Pest Sci. 90:521-530.

Davis, M. J., Purcell, A. H., and Thompson, S. V. 1978. Pierce's disease of grapevines: Isolation of the causal bacterium. Science 199:75-77.

Francis, M., Lin, H., Cabrera-La Rosa, J., Doddapaneni, H., and Civerolo, E. L. 2006. Genome-based PCR primers for specific and sensitive detection and quantification of Xylella fastidiosa. Eur. J. Plant Pathol. 115:203-213.

French, W. J. 1982. Reciprocal transmission of plum leaf scald and phony disease of peach. Phytopathology 72:452-453.

French, W. J., and Crocker, T. E. 1980. Phony peach disease. Pages 51-56 in: Proceedings of the 39th Annual National Peach Council Convention, Orlando, FL.

Giampetruzzi, A., Loconsole, G., Boscia, D., Calzolari, A., Chiumenti, M., Martelli, G. P., Saldarelli, P., Almeida, R. P., and Saponari, M. 2015. Draft genome sequence of CO33, a coffee-infecting isolate of Xylella fastidiosa. Genome Announc. 3:e01472-15.

Giampetruzzi, A., Saponari, M., Almeida, R. P. P., Essakhi, S., Boscia, D., Loconsole, G., and Saldarelli, P. 2017. Complete genome sequence of the olive-infecting strain Xylella fastidiosa subsp. pauca De Donno. Genome Announc. 5:e00569-17.

Groves, R. L., Chen, J., Civerolo, E. L., Freeman, M. W., and Viveros, M. A. 2005. Spatial analysis of almond leaf scorch disease in the San Joaquin Valley of California: Factors affeting pathogen distribution and spread. Plant Dis. 89:581-589.

Haelterman, R. M., Tolocka, P. A., Roca, M. E., Guzmán, F. A., Fernández, F. D., and Otero, M. L. 2015. First presumptive diagnosis of Xylella fastidiosa causing olive scorch in Argentina. J. Plant Pathol. 97:393.

Harper, S. J., Ward, L. I., and Clover, G. R. 2010. Development of LAMP and real-time PCR methods for the rapid detection of Xylella fastidiosa for quarantine and field applications. Phytopathology 100:1282-1288. 
Hernandez-Martinez, R., Costa, H. S., Dumenyo, C. K., and Cooksey, D. A. 2006. Differentiation of strains of Xylella fastidiosa infecting grape, almonds, and oleander using a multiprimer PCR assay. Plant Dis. 90: 1382-1388.

Hopkins, D. L., and Thompson, C. M. 1984. Seasonal concentration of the Pierce's disease bacterium in 'Carlos' and 'Welder' muscadine grapes compared with 'Schuyler' bunch grape. HortScience 19:419-420.

Janse, J. D., and Obradovic, A. 2010. Xylella fastidiosa: Its biology, diagnosis, control and risks. J. Plant Pathol. 92:S35-S48.

Jimenez, L. G., and Ingalls, A. 1990. Vitis caribaea as a source of resistance to Pierce's disease in breeding grapes for the tropics. Vitis 262-270.

Krivanek, A. F., and Walker, M. A. 2005. Vitis resistance to Pierce's disease is characterized by differential Xylella fastidiosa populations in stems and leaves. Phytopathology 95:44-52.

Landa, B. B., Velasco-Amo, M. P., Marco-Noales, E., Olmo, D., López, M. M., Navarro, I., Monterde, A., Barbé, S., Montes-Borrego, M., Román-Écija, M., Saponari, M., and Giampetruzzi, A. 2018. Draft genome sequence of Xylella fastidiosa subsp. fastidiosa strain IVIA5235, isolated from Prunus avium in Mallorca Island, Spain. Microbiol. Res. Announc. 7:e01222-e18.

Ledbetter, C. A., and Rogers, E. E. 2009. Differential susceptibility of Prunus germplasm (subgenus Amygdalus) to a California isolate of Xylella fastidiosa. HortScience 44:1928-1931.

Livingston, S., Chen, J. C., and Civerolo, E. L. 2010. Seasonal behavior of Xylella fastidiosa causing almond leafscorch disease under field conditions and improved detection of the bacteria by means of array-PCR. J. Phytopathol. 158:40-45.

Luvisi, A., Aprile, A., Sabella, E., Vergine, M., Nicoli, F., Nutricati, E., Miceli, A., Negro, C., and De Bellis, L. 2017. Xylella fastidiosa subsp. pauca (CoDiRO strain) infection in four olive (Olea europaea L.) cultivars: Profile of phenolic compounds in leaves and progression of leaf scorch symptoms. Phytopathol. Mediterr. 56:259-273.

Marcelletti, S., and Scortichini, M. 2016. Genome-wide comparison and taxonomic relatedness of multiple Xylella fastidiosa strains reveal the occurrence of three subspecies and a new Xylella species. Arch. Microbiol. 198: 803-812.

Minsavage, G. V., Thompson, C. M., Hopkins, D. L., Leite, R. M. V. B. C., and Stall, R. E. 1994. Development of a polymerase chain reaction protocol for detection of Xylella fastidiosa in plant tissue. Phytopathology 84:456-461.

Mizell, R. F., and French, W. J. 1987. Leafhopper vectors of phony peach disease-Feeding site preference and survival on infected and uninfected peach, and seasonal response to selected host plants. J. Entomol. Sci. 22: $11-22$.

Neal, D. C. 1920. Phony peaches: A disease occurring in middle Georgia. Phytopathology 10:106-107.

Nome, S. F., Raju, B. C., Goheen, A. C., Nyland, G., and Docampo, D. 1980. Enzyme-linked immunosorbent-assay for Pierce's disease bacteria in plant tissues. Phytopathology 70:746-749.

Nunney, L., Schuenzel, E. L., Scally, M., Bromley, R. E., and Stouthamer, R. 2014. Large-scale intersubspecific recombination in the plant-pathogenic bacterium Xylella fastidiosa is associated with the host shift to mulberry. Appl. Environ. Microbiol. 80:3025-3033.

Oliveira, A. C., Vallim, M. A., Semighini, C. P., Araujo, W. L., Goldman, G. H., and Machado, M. A. 2002. Quantification of Xylella fastidiosa from citrus trees by real-time polymerase chain reaction assay. Phytopathology 92:1048-1054

Randall, J. J., French, J., Yao, S., Hanson, S. F., and Goldberg, N. P. 2011. First report of Xylella fastidiosa in peach in New Mexico. Plant Dis. 95:871.

Randall, J. J., Goldberg, N. P., Kemp, J. D., Radionenko, M., French, J. M., Olsen, M. W., and Hanson, S. F. 2009. Genetic analysis of a novel Xylella fastidiosa subspecies found in the Southwestern United States. Appl. Environ. Microbiol. 75:5631-5638.

Reisenzein, H. 2017. PCR assays for detection of Xylella fastidiosa: Review and comparison of published protocols. Pages 57-60 in: Xylella fastidiosa \& the Olive Quick Decline Syndrome (OQDS). A Serious Worldwide Challenge for the Safeguard of Olive Trees. Options Méditerranéennes. A. M. D'Onghia, S. Brunel, and F. Valentini, eds. CIHEAM, Bari.

Rodrigues, J. L. M., Silva-Stenico, M. E., Gomes, J. E., Lopes, J. R. S., and Tsai, S. M. 2003. Detection and diversity assessment of Xylella fastidiosa in field-collected plant and insect samples by using $16 \mathrm{~S}$ rRNA and gyrB sequences. Appl. Environ. Microbiol. 69:4249-4255.
Ruel, J. J., and Walker, M. A. 2006. Resistance to Pierce's disease in Muscadinia rotundifolia and other native grape species. Am. J. Enol. Vitic. 57: 158-165.

Sanderlin, R. S., and Heyderich-Alger, K. I. 2000. Evidence that Xylella fastidiosa can cause leaf scorch disease of pecan. Plant Dis. 84:1282-1286.

Saponari, M., Boscia, D., Altamura, G., Loconsole, G., Zicca, S., D’Attoma, G., Morelli, M., Palmisano, F., Saponari, A., Tavano, D., Savino, V. N., Dongiovanni, C., and Martelli, G. P. 2017. Isolation and pathogenicity of Xylella fastidiosa associated to the olive quick decline syndrome in southern Italy. Sci. Rep. 7:17723.

Schaad, N. W., Postnikova, E., Lacy, G., Fatmi, M. B., and Chang, C. J. 2004. Xylella fastidiosa subspecies: X. fastidiosa subsp. piercei subsp. nov., $X$. fastidiosa subsp. multiplex subsp. nov., and X. fastidiosa subsp. pauca subsp. nov. Syst. Appl. Microbiol. 27:290-300.

Schreiber, H. L., Koirala, M., Lara, A., Ojeda, M., Dowd, S. E., Bextine, B., and Morano, L. 2010. Unraveling the first Xylella fastidiosa subsp. fastidiosa genome from Texas. Southwest. Entomol. 35:479-483.

Schuenzel, E. L., Scally, M., Stouthamer, R., and Nunney, L. 2005. A multigene phylogenetic study of clonal diversity and divergence in North American strains of the plant pathogen Xylella fastidiosa. Appl. Environ. Microbiol. 71:3832-3839.

Simpson, A. J. G., Reinach, F. C., Arruda, P., Abreu, F. A., Acencio, M., Alvarenga, R., Alves, L. M. C., Araya, J. E., Baia, G. S., Baptista, C. S., Barros, M. H., Bonaccorsi, E. D., Bordin, S., Bove, J. M., Briones, M. R. S., Bueno, M. R. P., Camargo, A. A., Camargo, L. E. A., Carraro, D. M., Carrer, H., Colauto, N. B., Colombo, C., Costa, F. F., Costa, M. C. R., Costa-Neto, C. M., Coutinho, L. L., Cristofani, M., Dias-Neto, E., Docena, C., El-Dorry, H., Facincani, A. P., Ferreira, A. J. S., Ferreira, V. C. A., Ferro, J. A., Fraga, J. S., Franca, S. C., Franco, M. C., Frohme, M., Furlan, L. R., Garnier, M., Goldman, G. H., Goldman, M. H. S., Gomes, S. L., Gruber, A., Ho, P. L., Hoheisel, J. D., Junqueira, M. L., Kemper, E. L., Kitajima, J. P., Krieger, J. E., Kuramae, E. E., Laigret, F., Lambais, M. R., Leite, L. C. C., Lemos, E. G. M., Lemos, M. V. F., Lopes, S. A., Lopes, C. R., Machado, J. A., Machado, M. A., Madeira, A. M. B. N., Madeira, H. M. F., Marino, C. L., Marques, M. V., Martins, E. A. L., Martins, E. M. F., Matsukuma, A. Y., Menck, C. F. M., Miracca, E. C., Miyaki, C. Y., Monteiro-Vitorello, C. B., Moon, D. H., Nagai, M. A., Nascimento, A. L. T. O., Netto, L. E. S., Nhani, A., Nobrega, F. G., Nunes, L. R., Oliveira, M. A., de Oliveira, M. C., de Oliveira, R. C., Palmieri, D. A., Paris, A., Peixoto, B. R., Pereira, G. A. G., Pereira, H. A., Pesquero, J. B., Quaggio, R. B., Roberto, P. G., Rodrigues, V., Rosa, A. J. D., de Rosa, V. E., de Sa, R. G., Santelli, R. V., Sawasaki, H. E., da Silva, A. C. R., da Silva, A. M., da Silva, F. R., Silva, W. A., da Silveira, J. F., Silvestri, M. L. Z., Siqueira, W. J., de Souza, A. A., de Souza, A. P., Terenzi, M. F., Truffi, D., Tsai, S. M., Tsuhako, M. H., Vallada, H., Van Sluys, M. A., Verjovski-Almeida, S., Vettore, A. L., Zago, M. A., Zatz, M., Meidanis, J., Setubal, J. C., and Org, X. C. 2000. The genome sequence of the plant pathogen Xylella fastidiosa. Nature 406: 151-157.

Turner, W. F. 1949. Insect vectors of phony peach disease. Science 109:87-88. Van Sluys, M. A., de Oliveira, M. C., Monteiro-Vitorello, C. B., Miyaki, C. Y., Furlan, L. R., Camargo, L. E. A., da Silva, A. C. R., Moon, D. H., Takita, M. A., Lemos, E. G. M., Machado, M. A., Ferro, M. I. T., da Silva, F. R., Goldman, M. H. S., Goldman, G. H., Lemos, M. V. F., El-Dorry, H., Tsai, S. M., Carrer, H., Carraro, D. M., de Oliveira, R. C., Nunes, L. R., Siqueira, W. J., Coutinho, L. L., Kimura, E. T., Ferro, E. S., Harakava, R., Kuramae, E. E., Marino, C. L., Giglioti, E., Abreu, I. L., Alves, L. M. C., do Amaral, A. M., Baia, G. S., Blanco, S. R., Brito, M. S., Cannavan, F. S., Celestino, A. V., da Cunha, A. F., Fenille, R. C., Ferro, J. A., Formighieri, E. F., Kishi, L. T., Leoni, S. G., Oliveira, A. R., Rosa, V. E., Sassaki, F. T., Sena, J. A. D., de Souza, A. A., Truffi, D., Tsukumo, F., Yanai, G. M., Zaros, L. G., Civerolo, E. L., Simpson, A. J. G., Almeida, N. F., Setubal, J. C., and Kitajima, J. P. 2003. Comparative analyses of the complete genome sequences of Pierce's disease and citrus variegated chlorosis strains of Xylella fastidiosa. J. Bacteriol. 185:1018-1026.

Wells, J. M., Raju, B. C., and Nyland, G. 1983. Isolation, culture, and pathogenicity of the bacterium causing phony disease of peach. Phytopathology 73:859-862.

Wells, J. M., Weaver, D. J., and Raju, B. C. 1980. Distribution of Rickettsialike bacteria in peach, and their occurrence in plum, cherry and some perennial weeds. Phytopathology 70:817-820. 